\title{
Prospective Teachers' Knowledge of Evaluating Student Errors on Area Conservation Task
}

\author{
Rooselyna Ekawati, Ahmad Wachidul Kohar*, Masriyah Masriyah, Abdul Haris Rosyidi, Budi Priyo Prawoto, and \\ Evangelista Lus Windyana Palupi \\ Faculty of Mathematics and Natural Science, Universitas Negeri Surabaya, Indonesia
}

\begin{abstract}
The data of conjecturing student errors were analyzed by focusing on possible errors of triangle area on a conservation task, while PSTs' responses of student errors were scrutinized using four strands: mathematical focus, pedagogical action, form of address, and degree of student error use. Results revealed that while PSTs tend to identify as well as interpret the existence of mathematical errors from the conceptual aspect on triangles with the same sizes of height and base, few PSTs could evaluate student errors employing the formal structure of area conservation concept on triangles with the different sizes of height and base. Regarding PST's responses, PSTs tend to agree with facilitating students to investigate the congruence of base and height of triangles in constructing the concept of triangle area measurement. However, they preferred to choose pedagogical action by reexplaining the main feature of the task solution instead of using student errors as a tool to probe student thinking or provide cognitive conflicts. Furthermore, most of the PST also don't use student errors as a tool to reconstruct a whole lesson indicating learning trajectory on area conservation concepts, but as a steppingstone to correct subsequent errors.
\end{abstract}

Keywords: Conservation Task, PSTs, Student Errors

\section{Introduction}

The term "conservation" of an area refers to the invariance of the quantitative value of the area of a geometrical shape even though the shape is converted into different forms qualitatively (Piaget, Inhelder \& Szeminka, 1960 as cited in [1]). Many scholars consider that an understanding of area conservation has been considered an important first step for students to master the concept of area measurement adequately. With area conservation ideas, students can start with familiar shapes (e.g., rectangles), cut, paste, and then rearrange different parts of shapes into new shape (e.g., parallelograms, triangles, rhombus, kite, etc). When students do these activities, they will understand that the concept of area conservation is an important prerequisite knowledge in measuring area so that finally they can understand how to construct area formulas geometrically using this concept [2].

However, the understanding on area conservation is challenging and problematic for students. Research reported several findings related to students' difficulties and errors in completing assignments on area conservation. This is related to the difficulty of students determining the area of a triangle even though they already understand the conservation area on a parallelogram [3], errors in determining the area of a rectangle when the tiles that make up the rectangular model are arranged in different ways even though the number is fixed [4], the use of visual estimations that are not followed by formal visual reasoning which makes it quite unreliable to justify the area of two triangles with different side lengths [1].

A more specific finding about the idea of conservation of area is related to finding the height of an obtuse triangle which students often make mistakes [5]. The errors are around the measurement of triangle area carried out by students using ready-made formulas: $1 / 2 \times$ base $\times$ height, which allows them to rely solely on procedural understanding in solving any area-related problems [6]. According to Hong and Runnals [2], the ability to find the height of a non-prototypical triangle, i.e., a triangle other than equilateral, isosceles, or one right triangle, is important for understanding the fact that the areas of incongruent shapes can be the same although they differ in their physical attributes.

Despite research on exploration of content and pedagogical knowledge of prospective teachers on geometry topics has been reported by previous researchers, for example, by Hong and Runnals [2], Baturo and Nason [7], Murphy [8], and Livy et al [9], there is still much that needs to be understood about the knowledge of prospective teachers on area measurement topics, especially those related to conservation areas. In content knowledge, this exploration can focus on the

\footnotetext{
* Corresponding author: ahmadkohar@unesa.ac.id
} 
nature of the conservation area concept as well as the consequences of relevant mathematical properties. In terms of pedagogical knowledge, this can focus on exploring the types of student strategies in completing conservation area-based tasks and the possible errors or misconceptions associated with them. Thus, to help students present and construct area formulas conceptually using area conservation ideas, teachers should have a fundamental and solid understanding of this concept as well as how to choose between several visual strategies [2].

However, a weak mathematical understanding of area conservation is not only experienced by students, but also by people of all ages, including prospective teachers and teachers [7-8]. Hong and Runnals [2] found that the prospective mathematics teacher in their research had difficulty in determining the base and height of incongruent figures even though the pictures had the same base length and height. They tend to rely solely on visual comparisons, and are often distracted by irrelevant features, such as the lengths of the sides of the base and the angles of the triangle. It is necessary to expand the scope of conservation area tasks to triangles with different physical attributes to understand the content knowledge of prospective teachers more accurately. This, for example, can be undertaken by assigning not only tasks that use the same base and height, but also those that use different bases and heights for the same area.

Pedagogically, scholars believe that the findings on students' frequent misunderstanding of area measurement and the tendency of teachers to present procedural strategies, re-explain concepts, or pedagogical strategies that emphasize the use of the concept of conservation of area in area measurement depend on initial content knowledge and how the teacher responds to students' errors. In this regard, Runnalls \& Hong [10] suggested prospective teacher to revisit the formula of triangle formula by suggesting students to use some strategies demonstrating the formula and asking them to evaluate its validity and accuracy. The strategies include using one half of a rectangle, one half of the height of an obtuse triangle, and one half of the base of an obtuse triangle. Thus, understanding of prospective teacher choices on providing instructions accommodating such suggestions is indispensable since it is not only intriguing but also less researched.

Researchers investigated prospective teachers' content and pedagogical knowledge on geometrical concepts through some analytical frameworks. Son [11] scrutinizes teacher response on students; work on similar triangle task by focusing on aspects of mathematical/instructional focus, pedagogical action, form of address, degree of student error, and act of communication barrier. Hu, Son, and Hodge [12] also applied such a framework to analyze teacher responses on algebraic tasks. In this research, the authors applied the same framework used by Son [11] to investigate teacher evaluation on the students' work on area conservation task. Therefore, this research aims to analyze prospective teachers' evaluation in the form of conjectures and responses on triangle-area conservation task.

\section{Research Method}

The investigation follow two stages as follows: 1) administering a questionnaire of area problem tasks to a sample of 28 prospective teachers who were studying at an elementary education program in a university in Surabaya, and 2) analysing the prospective teachers' response on the questionnaire.

In administrating the questionnaire, the participants worked on a discussion forum provided in a learning management system (LMS) for the course "Mathematics Learning in Elementary Grade". Within this forum, every participant provided his/her responses on the tasks. There were two area conservation tasks (Figure 1) administrated to the participants, which respectively assess prospective teachers' content and pedagogical knowledge of area conservation on triangles having the same bases and altitudes, and area conservation on triangles having different bases and altitudes.

Task 1

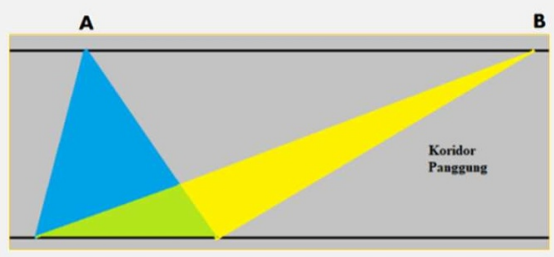

Two lights A and B illuminate the corridor wall of a stage as shown above. Zahra thinks that the light beam A covers the corridor wall more widely than the lamp B.

In your opinion, is Zahra's statement, correct?

$\checkmark$ If correct, please provide reasons that might underlie Zahra's statement.

$\checkmark$ If incorrect, explain what errors the basis for Zahra's statement might be. Then, provide examples of appropriate mentoring that can help Zahra understand the concepts that underlie solving the problem.

Explain in as much detail as possible.

Task 2

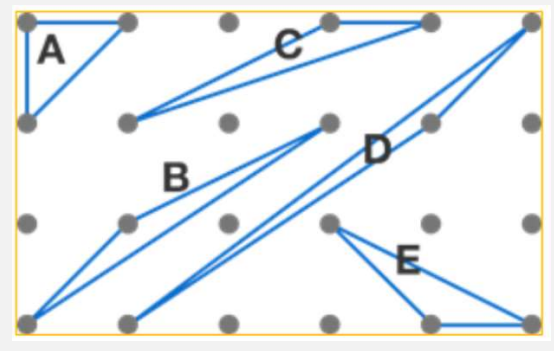

Zahra argues that no two triangles in the picture above have the same area. In your opinion, is Zahra's statement, correct?

$\checkmark$ If correct, provide reasons that might underlie Zahra's statement. 
$\checkmark$ If incorrect, explain what errors the basis for Zahra's statement might be. Then, provide examples of appropriate mentoring that can help Zahra understand the concepts that underlie solving the problem.

Explain in as much detail as possible

Fig.1. Area conservation task

Results of the prospective teachers' responses on task in figure 1 were then analysed using an analytical framework as shown in table 1. The framework was adapted primarily from the work of Son [11] proposing aspects of teacher evaluation on students' errors and the work of Hong and Runnals [2] examining prospective teachers' responses on whether they indicate reliance on visual analyses without adequate justification or not.

Table 1. Analytical framework of data analysis

\begin{tabular}{|c|c|}
\hline Collected data & Aspects of data analysis \\
\hline \multirow{3}{*}{$\begin{array}{l}\text { Participants' } \\
\text { identification } \\
\text { of student } \\
\text { errors might } \\
\text { occur when } \\
\text { solving area- } \\
\text { conservation } \\
\text { problems }\end{array}$} & $\begin{array}{l}\text { 1. Whether the prospective } \\
\text { teachers correctly determined } \\
\text { that the Zahra's statements } \\
\text { given as the information of the } \\
\text { problem is incorrect }\end{array}$ \\
\hline & $\begin{array}{l}\text { 2. What possible errors the } \\
\text { prospective teachers identified } \\
\text { from Zahra's statements }\end{array}$ \\
\hline & $\begin{array}{l}\text { 3. What underlying mathematics } \\
\text { the prospective teachers } \\
\text { diagnosed as reasons that result } \\
\text { in Zahra's errors. }\end{array}$ \\
\hline \multirow{3}{*}{$\begin{array}{l}\text { Participants' } \\
\text { responses on } \\
\text { student errors } \\
\text { in solving area- } \\
\text { conservation } \\
\text { problems? }\end{array}$} & $\begin{array}{l}\text { 4. Mathematical focus } \\
\text { (Conceptual vs. procedural) }\end{array}$ \\
\hline & $\begin{array}{l}\text { 5. Pedagogical action(s) (Re- } \\
\text { explains, probes student } \\
\text { thinking, suggests cognitive } \\
\text { conflict, etc.) }\end{array}$ \\
\hline & $\begin{array}{l}\text { 6. Form of address (Show-tell vs. } \\
\text { give-ask) }\end{array}$ \\
\hline
\end{tabular}

\section{Results and Discussion}

\subsection{Identification of possible student errors on area conservation task}

Results of prospective teachers' responses on identifying student errors are summarized in table 2, 3 and 4.

Table 2 indicates that most of the participants' responses are regarded as correct answer indicated by the responses claiming that triangles with the same bases and the same altitudes have the same area. This can be seen from a response indicated by figure 2 . However, one participant assumed that the two area is different in area since she/he does not consider the base, altitude, or relevant area of the shape in the corroder but relies on visual analysis to determine the corridor with a larger area. This finding is also found in prospective teachers who failed in measuring triangle area in the research of Hong and Runnals [2].

Menurut saya ada 3 segitiga dengan luas yang sama. Yaitu segitiga A, C, E. Hal itu didapat dari paniang alas dan tinggi yang sama. Tinggi segitia tersebut didapat dari 90 derajat dari masing-masing alas, sehingga ketiga segitiga mempunyai tinggi yang sama.

Translation: I think there are 3 triangles with the same area. That is triangle A, C, E. It is obtained from the length of the base and the same height. The height of the triangle is obtained from 90 degrees from each base, so all three triangles have the same height.

Fig.2. Response 1

Table 2. Response to Zahra's statement

\begin{tabular}{|c|c|c|c|}
\hline Task 1 & f & Task 2 & f \\
\hline $\begin{array}{l}\text { Code 111: } \\
\text { Incorrect } \\
\text { statement } \\
\text { Code } 112 \\
\text { Statements } \\
\text { can be } \\
\text { correct or } \\
\text { false } \\
\text { Code 113: } \\
\text { Correct } \\
\text { statement }\end{array}$ & 25 & $\begin{array}{l}\text { Code 211: } \\
\text { Incorrect statement, } \\
\text { assumes that there are at } \\
\text { least three triangles that } \\
\text { have the same area, namely } \\
\text { triangles that have the same } \\
\text { base and height (triangles } \\
\text { A, C, and E), and assumes } \\
\text { that the three triangles have } \\
\text { areas that are not the same } \\
\text { as triangles -other triangles } \\
\text { with different bases and } \\
\text { heights, namely triangles B } \\
\text { and D } \\
\text { Code } 212 \text { : } \\
\text { Incorrect } \\
\text { assumes that all triangles } \\
\text { have the same area } \\
\text { Code } 213 \text { : } \\
\text { The statement is correct, } \\
\text { assuming that all triangles } \\
\text { have different areas from } \\
\text { each other (area of triangle } \\
\text { A } \neq \text { area of triangle B } \neq \text { area } \\
\text { of triangle } \mathrm{C} \neq \text { area of } \\
\text { triangle D } \neq \text { area of triangle } \\
\text { E. }\end{array}$ & 12 \\
\hline
\end{tabular}

Some possible errors identified from Zahra's statement is given as follows.

Table 3. Possible errors they identified from Zahra's statements

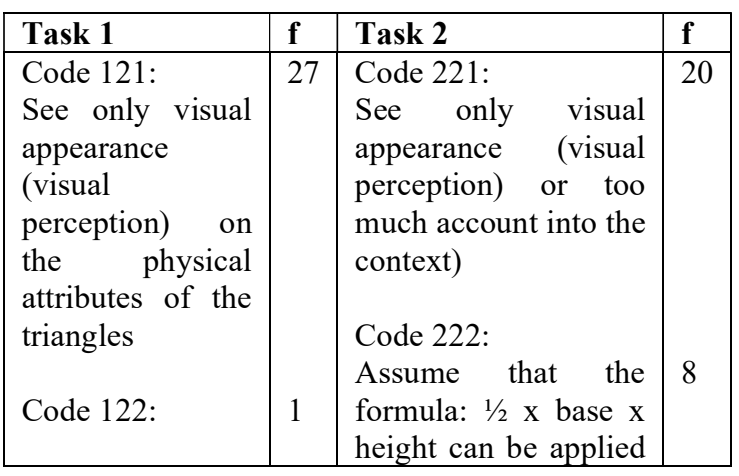




\begin{tabular}{|l|l|l|}
\hline $\begin{array}{l}\text { Difficult to find } \\
\text { the altitude of } \\
\text { each of the } \\
\text { triangles }\end{array}$ & $\begin{array}{l}\text { directly to all triangles } \\
\text { by looking at the } \\
\text { length of the base and } \\
\text { the height of each } \\
\text { triangle. }\end{array}$ \\
\hline
\end{tabular}

Table 3 indicates that most participants tend to explain that errors might occur due to the use of irrelevant visual analysis. This can be seen from an example of response 2 describing possible errors caused by taking the visual information too much into account so that no mathematical reasons are provided to explain the phenomena of beam lighting on the corridor.

Menurut saya, pendapat Zahra kurang tepat. Kesalahan yang mungkin mendasari pernyataan Zahra tersebut adalah kemungkinan dia melihat dari arah datangnya sinar. Berdasarkan gambar, titik A ada tengah menyorot objek secara langsung sehingga terlihat lebih luas. Sedangkan titik B ada di ujung panggung dan jarak dari ujung panggung terhadap objek terlihat lebih jauh. Hal inilah yang mungkin membuat Zahra berasumsi bahwa luas sinar lampu A lebih besar dari luas sinar lampu B

Translation: In my opinion, Zahra's opinion is not quite right. The error that may underlie Zahra's statement is the possibility that she saw from the direction of the light. Based on the picture, point $\mathrm{A}$ is in the middle highlighting the object directly so it looks wider. While point $\mathrm{B}$ is at the end of the stage and the distance from the end of the stage to the object looks farther. This is what might make Zahra assume that the area of the lamp A is larger than the area of the lamp B.

Figure 3. Response 2 related to possible errors

Meanwhile, irrelevant visual analysis that a student error might occur on task 2 is also found in the participant describing that finding the base and altitude of a slanted figure such as triangle B and D is impossible (Figure 4). Thus, students do not have any idea to compare those two triangles with the other three triangles (A, C, E).

* Kesalahan yang mendasari pernyataan Zahra kemungkinan disebabkan:
- Hanya sepintas melihat gambar segitiga tanpa menghitung luas segitiga
- Kesulitan menentukan alas segitiga pada segitiga B dan D karena sis segitiga semua berupa garis
miring sehingga menurutnya tidak bisa mencari luas segitiga tersebut dengan menggunakan rumus
dasar mencari luas segitiga

Fig.4. Response 3 related to possible errors

According to Hong and Runnals [2], the ability to understand that the fact that non-prototypical triangular shapes, such as shapes shown in task 1 and 2 (Figure 1) where there are differences in their physical attributes, may have the same area even though they are not congruent, is an important point in the concept of area conservation of the triangle.

Table 4. Possible underlying mathematics diagnosed as reasons that result in Zahra's errors.

\begin{tabular}{|l|l|l|l|}
\hline Task 1 & f & Task 2 & f \\
\hline Code 131: & 25 & Code 231: & 28 \\
\hline
\end{tabular}

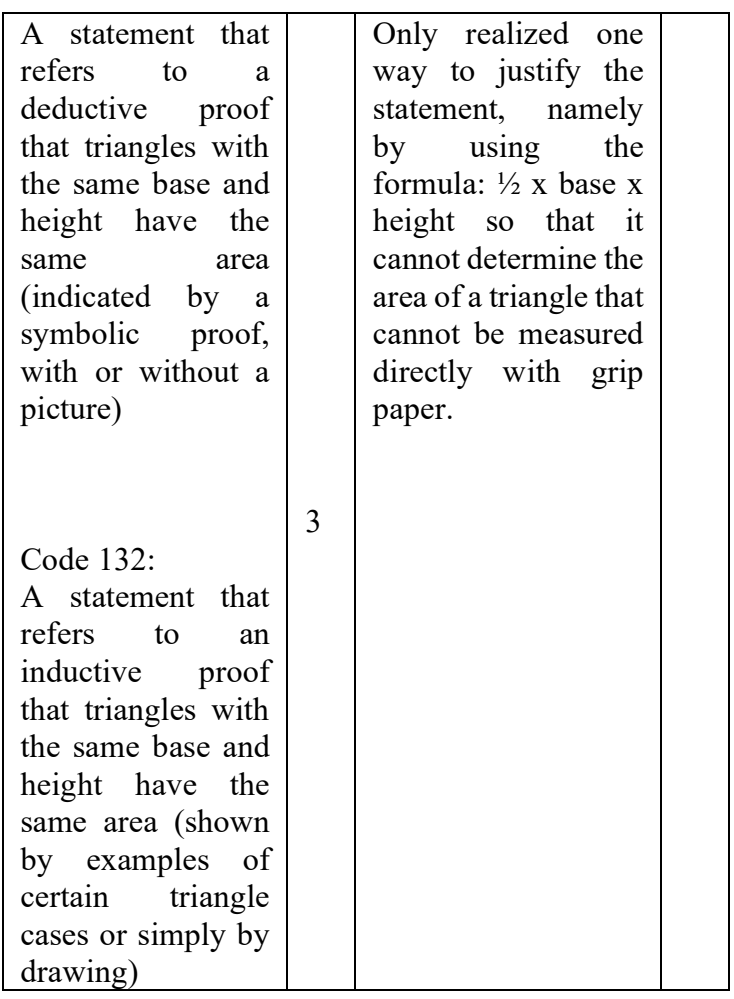

Responses in table 4 points out that the choices of mathematics underlying student errors can be explained through whether the students are able to use a more flexible strategy to find the area of triangle, instead of only one single strategy, which the triangle area formula. Thus, the strategy of using one-half rectangle, obtuse triangle and half of the height, and alike [10] maybe further explored to verify the formula of triangle area.

\subsection{Pedagogical responses on possible student errors on area conservation task}

Results of prospective teachers' responses on possible student errors on area conservation task are summarized in table 5, 6 and 7 .

Table 5. Response regarding mathematical focus

\begin{tabular}{|l|l|l|l|}
\hline Task 1 & f & Task 2 & f \\
\hline $\begin{array}{l}\text { Conceptual } \\
\text { Code 141: } \\
\text { Concern on } \\
\text { learning } \\
\text { recommendations } \\
\text { that emphasize } \\
\text { the understanding } \\
\text { that the base and } \\
\text { the same height in } \\
\text { a triangle have the } \\
\text { same area, } \\
\text { without or by } \\
\text { showing the } \\
\text { length of the } \\
\text { base/height. }\end{array}$ & $\begin{array}{l}\text { Concern } \\
\text { learning } \\
\text { recommendations } \\
\text { that emphasize the } \\
\text { understanding that } \\
\text { triangles that have } \\
\text { the same base and } \\
\text { height have the } \\
\text { same area, even } \\
\text { though they are not } \\
\text { congruent with each } \\
\text { other, or show a } \\
\text { strategy that the area } \\
\text { of the main triangle }\end{array}$ & \\
\hline
\end{tabular}




\begin{tabular}{|c|c|c|c|}
\hline $\begin{array}{l}\text { Procedural } \\
\text { Code 142: } \\
\text { Concern } \\
\text { learning } \\
\text { recommendations } \\
\text { that emphasize } \\
\text { the calculation of } \\
\text { the area of each } \\
\text { triangle with the } \\
\text { triangle area } \\
\text { formula: } \mathrm{x} \text { base } \mathrm{x} \\
\text { height using the } \\
\text { length of the base } \\
\text { and the height } \\
\text { given. }\end{array}$ & 2 & $\begin{array}{l}\text { is the area of the } \\
\text { enclosing rectangle } \\
\text { less the three } \\
\text { external right- } \\
\text { angled triangles } \\
\text { Procedural } \\
\text { Code } 242 \text { : } \\
\text { Concern } \\
\text { learning } \\
\text { recommendations } \\
\text { that emphasize the } \\
\text { calculation of the } \\
\text { area of each triangle } \\
\text { with the triangle } \\
\text { area formula: } 1 / 2 \mathrm{x} \\
\text { base } \mathrm{x} \text { height using } \\
\text { the length of the } \\
\text { base and the height } \\
\text { given. }\end{array}$ & 10 \\
\hline
\end{tabular}

Responses on table 5 indicates that most prospective teachers agree with the idea of the use of conceptual understanding of area conservation for a triangle to help students reduce any errors by focusing on the behaviour of the base and the height of the triangle, that is whether they have the same measure or not. This idea is crucial since many misconceptions or difficulties of prospective teachers, as found by Bilik [13], are determined related to the concept of height of a triangle, which is the prerequisite knowledge for triangle are concepts.

Table 6. Response related to pedagogical action (s)

\begin{tabular}{|c|c|c|c|}
\hline Task 1 & f & Task 2 & f \\
\hline $\begin{array}{l}\text { Re-explain } \\
\text { Code 151: } \\
\text { Explain directly to } \\
\text { students about the } \\
\text { concept and the } \\
\text { correct solution to } \\
\text { the given problem } \\
\text { Suggest probes } \\
\text { student thinking } \\
\text { Code 152: } \\
\text { Presents a visual } \\
\text { diagram, } \\
\text { recommends } \\
\text { alternative } \\
\text { procedures, such } \\
\text { as partitioning a } \\
\text { shape into smaller } \\
\text { pieces, each of } \\
\text { which, when } \\
\text { arranged, will have } \\
\text { the same area, or } \\
\text { shifting the corner } \\
\text { points while } \\
\text { retaining the sides } \\
\text { of the base }\end{array}$ & 24 & $\begin{array}{l}\text { Re-explain } \\
\text { Code 251: } \\
\text { Explain directly to } \\
\text { students by } \\
\text { presenting examples } \\
\text { of working on } \\
\text { determining the area } \\
\text { of each given } \\
\text { triangle without } \\
\text { regard to the order } \\
\text { of triangle choices. } \\
\text { Suggest probes } \\
\text { student thinking } \\
\text { Code } 252 \text { : } \\
\text { Presenting the } \\
\text { construction of the } \\
\text { formula for the area } \\
\text { of a triangle with the } \\
\text { help of manipulative } \\
\text { media or assisted by } \\
\text { technology or } \\
\text { guiding students to } \\
\text { see the area of a } \\
\text { triangle as a result of } \\
\text { subtracting the area } \\
\text { of a rectangle with } \\
\text { three other right } \\
\text { triangles. }\end{array}$ & 18 \\
\hline
\end{tabular}

Table 6 indicates that participants tend to agree that probing students to think of idea of area conservation in improving their understanding of triangle is suggested for alternative pedagogical actions. The example in figure 5 draws on a set of steps from cutting, pasting, and rearranging the smaller parts of the initial triangle into a new one as standard activity carried out to evaluate area conservation concept on a triangle [2].

$\begin{aligned} & \text { 1. Saya mengajak Zahra untuk menemukan konsep dasar dari luas sebuah bidang, yaitu melalui } \\ & \text { bentuk puzzel. zahra bisa menggunting salah satu segitiga yang tidak saling menutupi, kemudian } \\ & \text { potongan-potongan puzzel tersebut dilitatakan di salas satu segitiga maka akan ditemukan bahwa } \\ & \text { kedua sorot lampu tersebut luas atau besar sorot lampunya adalah sama. }\end{aligned}$
$\begin{aligned} & \text { Translation: I invited Zahra to find the basic concept of the area } \\ & \text { of a field, namely through the form of puzzles. Zahra can cut out } \\ & \text { one of the triangles that do not cover each other, then the puzzle } \\ & \text { pieces are placed in one of the triangles, it will be found that the } \\ & \text { two beams are the same area or the size of the beam. }\end{aligned}$

Fig.5. Response related to pedagogical action

Bilik [13] found at least six instructional strategies suggested by the participants of her study describing prospective teachers' pedagogical action responding to student errors on the concept of triangle area, i.e., by demonstration, cognitive conflict, didactic approach, and direct teaching. In her finding, the participants generally employed discussion strategy to guide students understand area conservation of triangle, while in this study the participants select probing to think of area conservation idea. Although the selection of instructional strategy seems different, the participants of both studies agree with delivering concept of conservation area on triangle conceptually, either by discussion or probes student thinking.

Table 7. Response related to form of address

\begin{tabular}{|c|c|c|c|}
\hline Task 1 & f & Task 2 & f \\
\hline $\begin{array}{l}\text { Code } 161 \\
\text { Show tell: } \\
\text { Teacher-centred } \\
\text { response in } \\
\text { providing } \\
\text { solutions, } \\
\text { alternative } \\
\text { representations, } \\
\text { or explanations } \\
\text { without } \\
\text { significant } \\
\text { student } \\
\text { involvement. For } \\
\text { example, } \\
\text { demonstrating } \\
\text { how to find the } \\
\text { area of each } \\
\text { triangle } \\
\text { pointing to the } \\
\text { parts of the } \\
\text { triangle that need } \\
\text { to be included in } \\
\text { the calculation. } \\
\text { Code 162 } \\
\text { Give-ask: }\end{array}$ & 23 & $\begin{array}{l}\text { Code } 261 \\
\text { Show tell: } \\
\text { Teacher-centred } \\
\text { response in } \\
\text { providing solutions, } \\
\text { alternative } \\
\text { representations, or } \\
\text { explanations } \\
\text { without significant } \\
\text { student } \\
\text { involvement. For } \\
\text { example, } \\
\text { demonstrating how } \\
\text { to calculate the area } \\
\text { of triangles B and C } \\
\text { by writing step by } \\
\text { step starting from } \\
\text { calculating the area } \\
\text { of a rectangle, the } \\
\text { area of each right } \\
\text { triangle, } \\
\text { subtracting the area } \\
\text { of a rectangle from } \\
\text { the total of three } \\
\text { other triangles. } \\
\text { Code } 262 \text { : }\end{array}$ & 8 \\
\hline
\end{tabular}




\begin{tabular}{|c|c|c|}
\hline $\begin{array}{l}\text { student-centered } \\
\text { and asks students } \\
\text { to provide } \\
\text { explanations for } \\
\text { work, resolve } \\
\text { cognitive } \\
\text { conflicts, or teach } \\
\text { other students. } \\
\text { For example, by } \\
\text { asking students to } \\
\text { explain the steps } \\
\text { in doing it, then } \\
\text { clarifying the } \\
\text { steps in } \\
\text { determining the } \\
\text { decision about } \\
\text { the truth of the } \\
\text { statement. }\end{array}$ & $\begin{array}{l}\text { Give-ask: } \\
\text { Ask students to } \\
\text { explain problem- } \\
\text { solving strategies, } \\
\text { especially in the } \\
\text { case of triangles that } \\
\text { do not have the same } \\
\text { base and height. }\end{array}$ & 20 \\
\hline
\end{tabular}

Most participants give agree with the idea of "giveask" as a form of addressing idea of area conservation to students. However, some participants like shown in figure 6 choose to show the situation and directly tell the students about the situation although probes student thinking, i. e. providing explanation that the two triangles have the same measure is suggested.

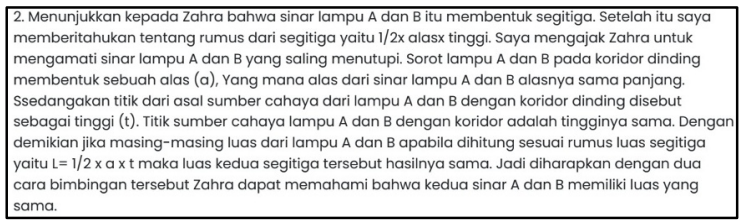

Translation: Show Zahra that the light rays A and B form a triangle. After that I told about the formula of the triangle which is $1 / 2 \mathrm{x}$ base $\mathrm{x}$ height. I invited Zahra to observe the lights of A and B overlapping each other. The beams A and B on the corridor wall form a base (a), where the bases of the light beams A and B are the same length. While the point from the origin of the light source from lamps A and B to the corridor wall is called the height ( $\mathrm{t})$. The light source points of lamps $\mathrm{A}$ and $\mathrm{B}$ with the corridor is the same height. Thus, if each area of lamps A and B is calculated according to the formula for the area of a triangle, namely $\mathrm{L}=1 / 2 \times \mathrm{x}$ a the the area of the two triangles is the same. So hopefully with these two ways of guidance Zahra can understand that both rays A and B have the same area.

Fig.6. Response related to form of address

Table 8. Degree of student error use

\begin{tabular}{|c|c|c|c|}
\hline Task 1 & f & Task 2 & f \\
\hline Code 171: & \multirow{11}{*}{0} & Code 171: & \multirow{12}{*}{0} \\
\hline Active & & Active & \\
\hline Fully use student & & Fully use student & \\
\hline errors as a focus on & & errors as a focus on & \\
\hline $\begin{array}{l}\text { improving broad- } \\
\text { based learning. For }\end{array}$ & & $\begin{array}{l}\text { improving broad- } \\
\text { based learning. For }\end{array}$ & \\
\hline example, choosing & & example, choosing & \\
\hline to rearrange the & & to rearrange the & \\
\hline learning sequence & & learning sequence & \\
\hline according to a & & according to a & \\
\hline learning trajectory & & learning trajectory & \\
\hline $\begin{array}{l}\text { for a broad } \\
\text { conservation topic. }\end{array}$ & & $\begin{array}{l}\text { for a broad } \\
\text { conservation topic. }\end{array}$ & \\
\hline Code 172: & & Code 172: & \\
\hline
\end{tabular}

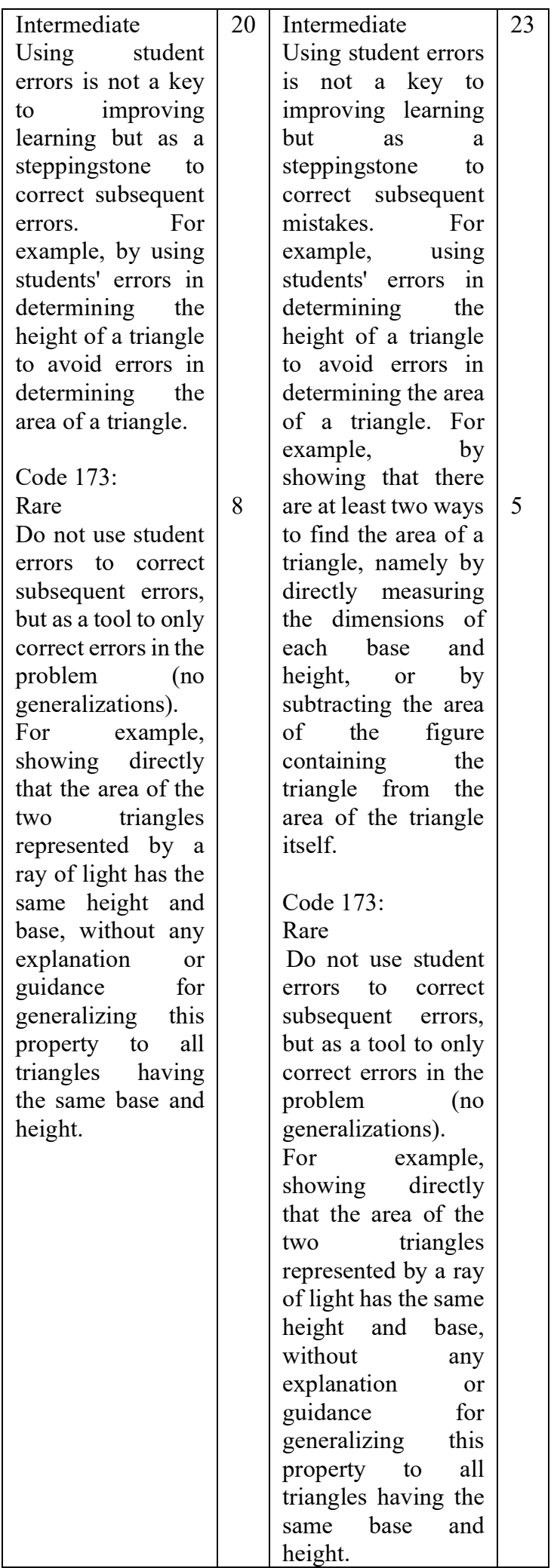

Regarding degree of student error use, none of the participants suggest using student error as focus to improve student understanding on area conservation concept, while the remaining participants give responses on intermediate or rare. This is interesting because a further exploration of how the prospective teachers use learning trajectory as basis to design their instructional 
strategies may explain this finding. According to Sztajn et al. [14], knowledge about student errors on specific topic in mathematics is a part of center of framework for teaching mathematics.

\section{Conclusion}

The results of this study indicate that prospective teachers are correct in identifying and interpreting the existence of a mathematical error from a triangle with the same height and base. However, some prospective teachers cannot fully evaluate how to apply the concept of conservation of area to triangles with different heights and bases. Furthermore, the pedagogical responses indicate pedagogical action by reexplaining the main feature of the task solution instead of using student errors as a tool to probe student thinking.

\section{References}

1. G Kospentaris, P Spyrou, D Lappas, Educ Studies in Math, 77 105-127 (2011).

2. D.S. Hong, C Runnalls, School Science and Mathematics, 120 262-272 (2020).

3. M. Kordaki, Educ Studies in Math, 52, 177-209 (2003)

4. C. Kamii, J Kysh The Journal of Mathematical Behavior, 25, 105-115 (2006).

5. A. Gutierrez, A. Jaime, J. of Math Teacher Educ 2, 253-275 (1999).

6. K. Zacharos, The Journal of Math Behavior, 25, 224-239 (2006)

7. A. Baturo, R. Nason, Educ Studies in Math 31, 235268 (1996)

8. C. Murphy, Journal of mathematics teacher education, 15, 187-206 (2012).

9. S. Livy, T. Muir, N. Maher, Math. Teacher Educ. and Development, 14, 91-112, (2012)

10. C. Runnalls, D. Hong, International Journal of Math. Educ. in Science and Tech., 51, 604-613 (2020).

11. J.W. Son,. Educ studies in Math, 84, 49-70 (2013)

12. Q. Hu, J.W. Son, L. Hodge, (2021). International Journal of Science and Math Education, 1-21.

13. A. Bilik. (2016). Pre-service middle school mathematics teachers' pedagogical content knowledge regarding the area of triangles (Doctoral dissertation, Master thesis). Yükseköğretim Kurulu Ulusal Tez Merkezi'nden edinilmiştir (Tez No. 439082)).

14. P. Sztajn, J. Confrey, P.H. Wilson, C. Edgington. Educational researcher, 41, 147-156 (2012) 